\title{
The Willingness to Pay for Flood Insurance $\partial$
}

Noelwah R. Netusil Stanley H. Cohn Professor of Economics, Department of Economics, Reed College, Portland,Oregon; netusil@reed.edu

Carolyn Kousky Executive director, Risk Management and Decision Processes Center, The Wharton School, University of Pennsylvania, Philadelphia; ckousky@wharton.upenn.edu

Shulav Neupane Research assistant, Department of Economics, Reed College, Portland, Oregon; shulavneupane@gmail.com

Will Daniel Research assistant, Department of Economics, Reed College, Portland, Oregon; williambdaniel@gmail.com

Howard Kunreuther James G. Dinan Professor Emeritus, Department of Operations, Information and Decisions, and co-director, Risk Management and Decision Processes Center, The Wharton School, University of Pennsylvania, Philadelphia; kunreuth@wharton.upenn.edu

\begin{abstract}
Flooding is the natural disaster that causes the most damage. Postflood, many families are not insured and do not have sufficient savings for rebuilding, and governmental aid can be limited. We undertake, using a stated preference survey, the first willingness-to-pay (WTP) elicitation for flood insurance in the United States. WTP increases with modeled flood risk and flood-risk perceptions. WTP for residents in our study area's 100year floodplain is $47 \%$ to $59 \%$ of the median flood insurance premium, which suggests the need for financial assistance for families who are at risk of flood damage and are unable to afford risk-based premiums. (JEL Q54, Q58)
\end{abstract}

\section{Introduction}

Flooding is the natural disaster that causes the most property damage in the United States. Flood risk is increasing in many places because of climate change and increased development in hazard-prone areas (see AECOM [2013]; Lin et al. [2016]). To recover financially from floods, households need flood insurance coverage. Contrary to many perceptions, federal disaster aid for victims in the United States is often limited or delayed,

Land Economics • February 2021 • 97 (1): 17-38

ISSN 0023-7639; E-ISSN 1543-8325

(C) 2021 by the Board of Regents of the

University of Wisconsin System making it an inadequate recovery source. ${ }^{1}$ In addition, roughly $44 \%$ of Americans do not have $\$ 400$ of liquid funds for an emergency, and the percentage is even higher $(52 \%)$ for those with only a high school education or less (Board of Governors of the Federal Reserve System 2017). As such, for many families there is no substitute for flood insurance. Despite this, many at risk for flooding do not have a flood insurance policy, and many who need the protection the most are least able to afford it.

Several studies have sought to identify the determinants of flood insurance demand. Unsurprisingly, they generally find take-up rates to be higher in areas where the hazard is greater (or risk perceptions are greater), and that take-up rates increase with higher levels of education and income as well as higher

\footnotetext{
${ }^{1}$ Federal assistance is only provided after large disasters that receive a federal disaster declaration. Localized flooding may fail to receive this assistance. Even if a declaration is issued, most declarations only authorize assistance to local governments. If authorized by the president, qualifying individuals can receive assistance from FEMA's Individual and Household Program (IHP). From 2005 to 2014, however, IHP was authorized in only $35 \%$ of major disaster declarations. These grants are capped at a bit over $\$ 33,000$ and for most events only average a few thousand dollars. According to FEMA (2016b, 5), "IHP is not a substitute for insurance and cannot compensate for all losses caused by a disaster; it is intended to meet basic needs and supplement disaster recovery efforts." Beyond these grants, the Small Business Administration offers disaster loans to households. These must be repaid, and for some families the extra debt is burdensome. In addition, many families may not qualify. The lowest-income families are discouraged from applying and sent to the FEMA Individual Disaster Assistance grants, which may be insufficient.
}

17 Appendix materials are freely available at http://le.uwpress.org and via the links in the electronic version of this article. 
home values (Kousky 2011; Landry and Jahan-Parvar 2011; Petrolia, Landry, and Coble 2013; Atreya, Ferreira, and Michel-Kerjan 2015; Brody et al. 2017). Atreya, Ferreira, and Michel-Kerjan (2015) find in Georgia that take-up rates increase by roughly $1 \%$ for each percentage point increase in the African American population in a county.

There is growing awareness that low- and middle-income households that need the financial protection of insurance are unable to afford it. Atreya, Ferreira, and Michel-Kerjan (2015) estimated an income elasticity for flood insurance of 0.39 using enrollment data in the National Flood Insurance Program (NFIP) in Georgia, and Kriesel and Landry (2004) estimated an income elasticity of 0.49 using NFIP data for nine coastal counties in six states. Hung (2009) estimated income elasticities of 0.45 and 0.50 in a contingent valuation study of willingness to buy flood insurance in Taiwan. Beyond looking at income elasticities, a recent study on the cost of flood insurance in New York City found that flood insurance was cost burdensome (which the authors define as contributing to a ratio of mortgage principle, interest, property tax, and insurance to income greater than 0.4) for roughly a quarter of owner-occupied residences (Dixon et al. 2017).

More than $90 \%$ of residential flood insurance in the United States is provided by the federal government via the NFIP. Unlike a typical private good, prices are not set competitively in the market but influenced by political values about the affordability and fairness of coverage. Not being subject to market pressure, the program's pricing is outdated and contains multiple cross-subsidies (Kousky, Lingle, and Shabman 2017); FEMA is modernizing rate-setting with a new approach being phased in beginning in 2021. Finally, demand is difficult to infer from market data because high-risk properties with a loan from a federally backed or regulated lender are required to purchase insurance, and consumer information about flood risk and insurance is low (Chivers and Flores 2002; Royal and Walls 2019). Thus, using the tools of contingent valuation to elicit homeowners' willingness to pay (WTP) for flood insurance could inform policy decisions about this program. To our knowledge, no such WTP elicitations have been undertaken in the United States, and we identify only three globally.

A WTP study for flood insurance conducted in the Netherlands estimated an income elasticity of 0.17 (Botzen and van den Bergh 2012). The context differs from ours in fundamental respects: flood insurance was not available in the Netherlands at the time of the study, and the country has not had major flooding since 1953 owing to investments in structural flood protection. Hung (2009) used a fuzzy contingent valuation method to value the WTP for flood insurance for two areas in Taiwan. A key finding from this study is that the fuzzy WTP regions are wide, which the author attributes to uncertainty in respondents' preference about paying a randomly selected bid amount for a flood insurance policy. Roder, Hudson, and Tarolli (2019) used an open-ended question to determine the WTP for flood insurance in the Veneto region of Italy, which does not have a well-developed market for private flood insurance. Model results were not reported due to a lack of "sufficient statistical quality," which the authors attribute to the many respondents reporting zero WTP or not answering the open-ended WTP question. We build on these studies by eliciting WTP for flood insurance in a very different context, one where there is already a flood insurance market but it is not competitive and is dominated by a public provider, which insures a population with different levels of underlying risk and sociodemographic characteristics.

The current study draws on contingent valuation methods to elicit WTP for flood insurance from a sample of residents in two low- to middle-income neighborhoods of Portland, Oregon, at risk of fluvial (river) and pluvial (rainfall) flooding. We administered a survey to residents in 2018 asking about their flood experiences, flood insurance purchases, perceptions of flood risk, and their WTP for flood insurance. We use a payment card elicitation, given the nature of our good, which is a currently available flood insurance policy, and we examine how WTP varies with income, risk perceptions, objective risk, previous experience with flooding, the length of time in one's current home, and respondent demographic characteristics. 
This study contributes to the literature in several ways. First, we report, for the first time, flood insurance income elasticities and annual WTP estimates for a study area in the United States. Second, we present annual WTP models using three different measures of objective risk, including a model that uses state-of-the-art hydrological estimates of predicted flood volume during a 100-year event. Third, the type of flooding that occurs in our study area-shallow flooding of $1-3 \mathrm{ft}$.-is not commonly studied. Fourth, our study area has a high percentage of properties that were built before flood insurance rate maps were produced for the area. As we discuss further, these properties have historically been paying discounted flood insurance premiums that are now being phased out, leading to escalating flood insurance rates. The study area also has a high poverty rate and a high percentage of foreign-born residents and residents who speak a language other than English at home.

\section{An Overview of Flood Insurance}

The NFIP, housed in the Federal Emergency Management Agency (FEMA), has been one of the primary flood management programs of the federal government since $1968 .^{2}$ Communities can voluntarily enroll in the NFIP, adopting minimum building codes and land use regulations; in exchange, their residents become eligible to purchase flood insurance. More than 22,000 communities participate in the program, including Portland (FEMA 2017).

Households can purchase building coverage of up to $\$ 250,000$ and contents coverage of up to $\$ 100,000$. Policy and claim administration are handled largely by private insurance companies in exchange for a fee, but the NFIP bears all of the risk of flood damage and sets premiums. Participation in the early years of the program was low, so in 1973, Congress required flood insurance on all federally backed loans or federally regulated mortgages for property located in a 100-year floodplain (i.e., areas where the annual likelihood of floods is greater than or equal to 1 in 100).

\footnotetext{
${ }^{2}$ For a detailed overview of the NFIP, see Kousky (2018).
}

Today, there are more than 5 million policies in force nationwide with just under 27,000 in Oregon and roughly 1,800 in Portland. ${ }^{3}$

FEMA also delineates the flood hazard in participating communities via Flood Insurance Rate Maps (FIRMs). These maps were developed largely to designate the boundary of the 100-year floodplain or special flood hazard area (SFHA). The SFHA is critical to implementing the NFIP for two reasons. First, mortgage lenders must require flood insurance on federally backed or regulated loans for houses in the SFHA. Second, in the SFHA, communities must adopt certain land use and building regulations, which require all new construction be elevated above the estimated base flood elevation. The maps also designate different flood zones, which have historically been used in setting insurance rates. The SFHA includes $\mathrm{V}$ zones and $\mathrm{A}$ zones. $\mathrm{V}$ zones indicate coastal areas subject to breaking waves, which is not applicable to Portland. There are several different A zones; of relevance for our study area are $\mathrm{AE}$ and $\mathrm{AH}$. AE is the standard 100-year floodplain where FEMA has also estimated the potential height of floodwaters in a 100-year flood event, referred to as the base flood elevation. $\mathrm{AH}$ refers to areas of shallow flooding of only 1-3 ft. Shallow flood areas probably have lower expected damages than areas that can experience deeper flooding, such as properties in the AE zones in our study area. The area outside the 100-year floodplain is referred to as zone $\mathrm{X}$.

The FIRMs were designed to implement NFIP requirements and assist in setting insurance premiums. They were not designed to be ideal risk communication products and have been criticized for creating a false binary perception of flood risk (i.e., perceiving there to be minimal risk outside the SFHA and uniform and more substantial risk inside the SFHA), for being out of date, and for not reflecting changing risk conditions, such as climate change (Joyce 2016; Office of Inspector General 2017; Shaw, Thompson, and Meyer 2013). Although FEMA is required to revisit maps every five years, updating maps must be

\footnotetext{
${ }^{3}$ Data available from FEMA at https://www.fema.gov/ policy-claim-statistics-flood-insurance.
} 
prioritized given the limited budget and time required to produce them.

FEMA is now modernizing its rating structure, an intiative referred to as Risk Rating 2.0. New premiums will start to be implemented in 2021. Historically, however, and at the time of our study, NFIP premiums were set based on annually updated rating tables (for more detail on this rating process, see Kousky, Lingle, and Shabman [2017]). Premiums varied by flood zone shown on the FIRM and by differences in housing characteristics, such as presence and type of basement, number of stories, and amount of coverage purchased.

There have been a few classes of policy holders who received discounted insurance premiums. The most important of these groups for our study area are referred to as pre-FIRM, which are properties that were constructed before FEMA had mapped the flood hazards in an area. These homes were given discounted premiums early in the program so as to not penalize owners who had built before floodplain regulations were adopted. Legislation passed in 2012 and 2014 began to phase out these discounts. Insurance premiums for preFIRM properties are now being increased between $5 \%$ and $18 \%$ every year until they reach full risk rates. Nationwide, on January 1, 2019, $40.4 \%$ of residential policies were pre-FIRM. In the two main ZIP codes that span our study area, the percentage was 75.6\% (FEMA 2019).

To encourage communities to adopt more flood mitigation measures, the NFIP created the Community Rating System (CRS) in 1990. Participating communities earn points for undertaking various risk management and risk reduction measures. As they accrue points, they move up levels from the lowest (class 10) to the highest (class 1). At each new level, residents in the community located in the SFHA get an additional 5\% reduction on their insurance premiums. Outside the SFHA, a $5 \%$ reduction in premiums is given for residents of class 7-9 communities, and a $10 \%$ reduction applies for class 1-6 communities. At the time of our study, Portland was a class 6 , which gave residents in the SFHA a 20\% reduction in premiums, while those in $\mathrm{X}$ zones received a $10 \%$ discount. The median cost of flood insurance for all single-family residential properties in the two ZIP codes that cover the majority of the study area was $\$ 777$ in 2018 (FEMA 2018). Properties in the $\mathrm{X}$ zone had a median flood insurance cost of $\$ 348$, and those in the A zone had a median flood insurance cost of $\$ 878$. These premiums reflect the CRS discount that Portland has earned.

Because Portland participates in the CRS, property owners in our study area's 100 -year floodplain receive multiple mailings each year from the city that describe the risk of flooding from living in the floodplain, the need to protect their property from flood damage, and a discussion about flood insurance requirements. Some residents in our study area who live outside the 100-year floodplain also receive mailers from the city about flood risk, for example, a map showing detour routes when roads are closed due to flooding.

\section{Study Area}

Our study area is composed of two adjoining neighborhoods in southeast Portland, Oregon: Lents and Powellhurst-Gilbert (see Figure 1a). Roughly 4,560 acres in total, these two neighborhoods are prone to flooding from Johnson Creek, which bisects the bottom part of the Lents neighborhood (Figure 1b), and the ephemeral Holgate Lake (Figure 1d). Just under $8 \%$ of our study area is in the 100 -year floodplain, and $3.7 \%$ of the study area is in the 500-year floodplain (Figure 1b). In the 100year floodplain, $70 \%$ of the area is categorized by FEMA as zone $\mathrm{AH}$, indicating only shallow floods, with the remaining 30\% in the AE zone (Figure 1c). When Johnson Creek overtops its banks, water flows downhill, so residents as far away as one mile from the creek are still in the mapped 100-year floodplain due to surface-water flooding (Figure 1b). Groundwater flooding affects properties in the Holgate Lake area (Figure 1d). ${ }^{4}$

Of the 10,413 single-family residential properties in the study area, 594 have a building footprint that is either fully inside or intersected by the 100-year floodplain, and 302 have a building footprint that is either inside

\footnotetext{
${ }^{4}$ We received too few responses to estimate the effect on WTP for respondents who are in the Holgate Lake area 100year floodplain separately from the Johnson Creek 100-year floodplain.
} 
Figure 1

Study Area and Floodplain Characteristics: (a) Study Area, (b) 100- and 500-Year Floodplains, (c) AE and AH Zones, and (d) FEMA Map Error and Holgate Lake

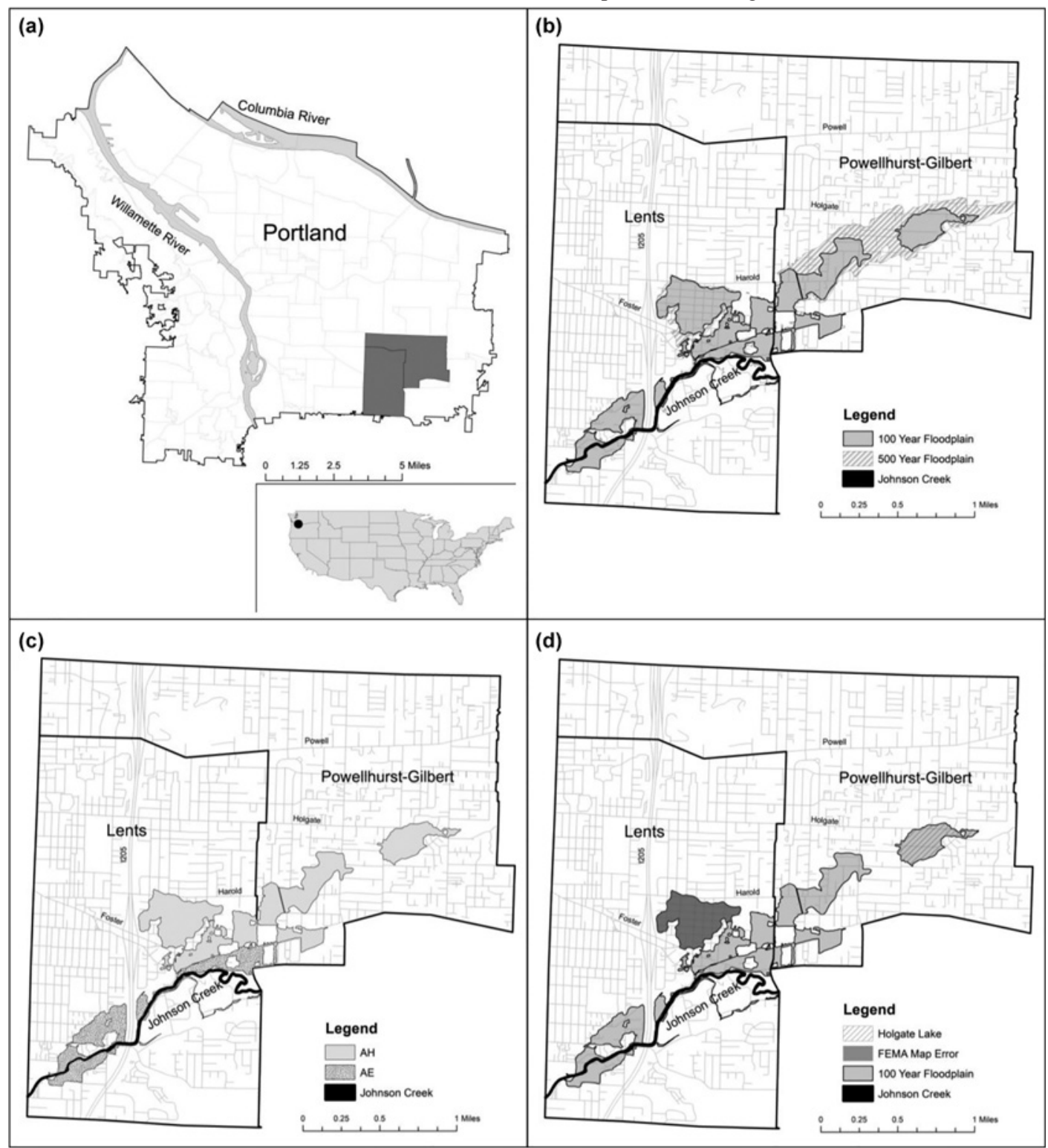

or intersected by the 500 -year floodplain. ${ }^{5} \mathrm{We}$ focus on building footprint (rather than tax lot boundary) to determine if a property is "in the floodplain" because properties with a building

\footnotetext{
${ }^{5}$ Properties with building footprints in both the 100- and 500-year floodplains are included only in the 100-year floodplain.
}

footprint inside or intersected by the 100-year floodplain with a federally-backed mortgage are required to have flood insurance. ${ }^{6}$ Around

\footnotetext{
${ }^{6}$ Netusil, Moeltner, and Jarrad (2019) examined the effect on property sale price from using building footprint, instead of the parcel's tax lot, and found a substantial positive bias when using tax lot to determine floodplain location.
} 
$90 \%$ of the properties in the 100 -year floodplain were built before the first FEMA FIRM went into effect in October 1980; the current FIRM is from 2004.

Johnson Creek, which is one of last free-flowing streams in the Portland metropolitan area, has reached flood stage 40 times since 1937 (National Oceanic and Atmospheric Administration 2019), with at least 8 floods causing major property damage (FEMA 2016a). Surface-water flooding occurs during the winter months as a result of intense precipitation, which is sometimes preceded by saturated soils, snow, or both (Lee and Snyder 2009). Record rainfalls in water years 1996 and 1997 caused an estimated $\$ 4.7$ million in damages (FEMA 2016a) with flooding along Johnson Creek lasting for several days during these events (Lee and Snyder 2009). Future flooding in the study area may be worse because of predicted increases in stream flows during the rainy winter months because of climate change (Chang, Watson, and Stecker 2017) and increased development in the watershed (Jung, Chang, and Moradkhani 2011).

Investments have been made in the study area by FEMA, city, regional, and state agencies, nonprofits, and private property owners to restore floodplain functionality and reduce property damage. Between 1990 and 2014, 104 acres in the study area were restored to reduce flood risk, such as by removing fill, creating side channels, and increasing the size of culverts (Jarrad 2016).

A major floodplain restoration project, the Foster Floodplain Natural Area, was completed in 2012 on a 63-acre site in the study area (Bureau of Environmental Services 2019). This project reduced nuisance flooding from once every other year to once every six years, on average, but it did not change the probability of a 100-year event. As part of the Foster Floodplain project, FEMA required a letter of map revision (LOMR) to be submitted. ${ }^{7}$ However, an error occurred in how FEMA recorded the LOMR when the restoration project was complete, which resulted in about 340 single-fam-

\footnotetext{
${ }^{7} \mathrm{~A}$ letter of map revision is a process to modify a small part of an existing FIRM before remapping is done for a community, usually to reflect a new investment in flood control.
}

ily residential properties (Figure 1d) being incorrectly removed from the 100-year floodplain (Jacob Sherman, pers.comm. 2018). This mapping error was discovered by the city after property owners and lenders were incorrectly notified by FEMA that these properties were no longer in a floodplain and that property owners were no longer required to purchase flood insurance even if the owners had a federally backed mortgage. City officials notified FEMA about the error, but it is unknown if or when FEMA contacted lenders about the mistake. This may lead to a difference in how property owners in the "FEMA map error" part of the 100-year floodplain view the risk of flooding and, in turn, their WTP for flood insurance. For example, it is conceivable that property owners who experienced this error have lower trust in FEMA estimates of risk or in FEMA programs broadly in a way that could influence their WTP.

The study area is one of the most diverse in Portland based on five-year (2013-2017) American Community Survey data for the census tracts that most closely align with the neighborhood boundaries. Sixty-four percent of study area residents are white (77\% for Portland as a whole), $17.1 \%$ are Asian, 5.7\% are Black or African American, and $16.4 \%$ are Hispanic or Latino (U.S. Census Bureau 2018). Study area residents are almost twice as likely to be foreign-born (27\%) as Portland residents (14\%), and 39\% speak a primary language at home other than English. Poverty rates are higher in our study area $(23.3 \%)$ than in Portland $(15.6 \%)$, and only $13 \%$ of residents (compared with 35\% for Portland) have a bachelor's degree or higher. In addition, slightly fewer residents in the study area are in owner-occupied housing (51\% compared with $56 \%$ in Portland as a whole).

In 2016, the study area was certified as an Oregon Solutions Project with a focus on preserving existing houses, enhancing industrial lands to promote job growth, and mitigating flood risk from Johnson Creek (Oregon Solutions 2017). Oregon Solutions Projects bring together local, state, and federal agencies with stakeholders to develop innovative strategies to address challenging public policy questions. Outcomes for our study area included a pilot flood insurance savings program for 
low-income residents in the 100-year floodplain (for an overview of the program, see Sherman and Kousky [2018]) and state-ofthe-art hydraulic modeling of predicted flood volume from a 100-year event (Gary Wolff, pers. comm. 2018), which we use as one measure of objective risk in our WTP models.

\section{Survey Design}

The survey design process followed best practices as described in Dillman, Smyth, and Christian (2014) and Johnston et al. (2017). Hard copies of the English version of our survey were pretested with economists with expertise in survey design, government agency and nonprofit staff who work in the study area, and two professionally moderated focus groups of residents from our study area. Residents were recruited to the focus group via Craigslist and were compensated for their time. Focus group members emphasized the importance of including community members who may not have access to a computer and who may not be native English speakers, so the final version of the survey was available in four languages-English, Spanish, Russian, and Vietnamese - and could be completed online or by requesting a hard copy.

Addresses of all single-family residential properties in our study area neighborhoods were obtained using the regional government's tax lot layer (Metro Data Resource Center 2018). This data set was cleaned-for example, to remove properties that were determined to not be single-family residential (such as vacant lots and commercial properties that were zoned single-family residential). All residents of the 1,186 properties with a tax lot inside or intersected by the 100- or 500 -year floodplain were invited to take the survey, as were 2,841 residents of randomly selected neighborhood properties from outside the floodplains.

Unique alphanumeric access codes were created for each property, which allowed us to link survey responses with individual property information. This identifier also allowed us to have respondents whose building footprint is inside or intersected by the 100-year floodplain answer a different WTP question than respondents outside the 100-year floodplain (more on this below).

Mailings took place between mid-August and mid-September 2018. The first two used professionally designed oversized postcards, and the final two were signed letters on college stationery. Focus group participants responded positively to including the Portland Housing Bureau as a study co-sponsor because of the bureau's role in implementing a flood insurance savings program in the study area (Sherman and Kousky 2018) and participants' belief that policies to reduce flood risk would require city agencies take a leadership role.

Survey respondents were offered a one-infive chance to win a $\$ 20$ gift card to a local grocery store, which was supplemented in the final two mailings with the chance to win a $\$ 150$ gift card. In addition to the four mailers, the survey was promoted by the local watershed council, by neighborhood residents on NextDoor and Facebook, and through neighborhood association websites, newsletters, and mailing lists. The survey website was closed in mid-October 2018. After accounting for the 225 undeliverable mailings, the overall response rate was $11.1 \%$. Response rates were $17.8 \%$ in the 100 -year floodplain, $9.9 \%$ in the 500 -year floodplain, and $9.9 \%$ outside the floodplains. The response rate is in line with prior studies on this topic (Brody et al. 2017; Dixon et al. 2017;) and is reasonable given the small financial compensation we provided and because renters, who occupy $49 \%$ of properties in our study area, were unlikely to complete the survey. ${ }^{8}$

All respondents answered survey questions about how long they had lived in their current home, their perceived flood risk, their past experience with flooding, their expected future flooding to their current house, whether they had flood insurance, and their insurance literacy. The survey questions for flood-risk perception, past flood experience, and expected future flooding are in Appendix A. The WTP elicitation varied by floodplain location. All respondents, regardless of their location inside or outside the 100-year floodplain, were

\footnotetext{
${ }^{8}$ Only 12 of the 395 respondents who answered the property ownership question were renters.
} 
presented with a scenario where they were asked to select their maximum annual WTP for a specific flood insurance policy from the perspective of a property owner located in the 100 -year floodplain in the study area neighborhoods. Those currently in the SFHA were told of this fact and then asked the WTP question, and those outside the SFHA were asked to consider their maximum annual WTP as if they were living in a SFHA. The full wording of each WTP elicitation is provided in Appendix B.

For efficient estimation, the WTP elicitation was done using a payment card instead of a dichotomous-choice response format because of the limited number of possible respondents in the 100- and 500-year floodplains (594 and 302 , respectively). Payment cards are not incentive compatible (Boyle 2017), but the nature of our marketed good, which is primarily provided by the NFIP, means that respondents cannot change premiums by acting strategically. It is also unlikely, even if a respondent perceives flood risk to be very low, that their maximum annual WTP for flood insurance is $\$ 0$ and payment cards appear to avoid the $\$ 0$ spike seen with other response formats (Boyle 2017).

Payment card values were drawn from the known range of NFIP premiums for single-family residential properties in the two ZIP codes that overlap our study area. In 2018 these ranged from a first percentile of $\$ 174$ to a 99th percentile of $\$ 3,202$ with $\$ 348$ as the 25 th percentile, a median of $\$ 777$, and $\$ 1,042$ as the 75th percentile (FEMA 2019). Focus group participants responded favorably to the payment card values, so these were used in the final version of the survey (see Appendix B).

\section{Housing, Geospatial Data, and Respondent Characteristics}

Survey respondents were asked to self-report demographic information. Using addresses and the unique identifier on each survey allowed us to link respondents to housing data, such as the size of each property's tax lot, building square footage, year built, and total assessed value (Metro Data Resource Center 2018). ArcGIS 10.5.1 was used to derive lo- cation variables, including a property's flood zone based on its building footprint (Metro Data Resource Center 2016a) and Euclidean distance to Johnson Creek (Metro Data Resource Center 2016b). The FEMA map error area was identified in consultation with city staff (Jacob Sherman, pers.comm. 2018). The estimated volume of flooding from a 100-year event was determined by overlaying building footprints (Metro Data Resource Center 2016a) for the largest structure on each single-family residential property with the projected flood inundation layer (Gary Wolff, pers. comm. 2018).

Table 1 shows the summary statistics for the self-reported demographic information of our respondents and their property characteristics as calculated for their residence. Compared with five-year (2013-2017) American Community Survey data for the census tracts that most closely align with the neighborhood boundaries (U.S. Census Bureau 2018), survey respondents are more likely to be older, be white, be employed full-time, and have a bachelor's degree or higher. The average household income, based on the midpoint of the income ranges provided in the survey, was $\$ 72,139$, which is higher than the study area's average income of $\$ 47,647 .{ }^{9}$ Compared with nonrespondents, respondent properties are significantly older, have homes with smaller building square footage, and are located closer to Johnson Creek. ${ }^{10}$ Lot square footage and total assessed value are not statistically different between respondents and nonrespondents. ${ }^{11}$

\section{WTP Distribution and Hypotheses}

As stated earlier, respondents in the floodplain were asked their maximum annual WTP based on their current home's location,

\footnotetext{
${ }^{9}$ Six respondents selected an income range of "More than $\$ 200,000$." These respondents were assigned an income of $\$ 250,000$.

${ }^{10}$ The income and age values are an average of the median values for the study area census tracts.

${ }^{11} \mathrm{We}$ are unable to correct our estimates for nonrespondents. Our population of interest is property owners; Portland does not track which properties are rented, so we cannot differentiate between property owners and renters.
} 
Table 1

Survey Respondent and Property Characteristics

\begin{tabular}{lccrrr}
\hline Variable & Average & $\begin{array}{c}\text { Standard } \\
\text { Deviation }\end{array}$ & Minimum & Maximum & ACS Data \\
\hline Age (years) & 52.08 & 15.86 & 22 & 97 & 35.19 \\
Household size & 2.57 & 1.39 & 1 & 11 & \multicolumn{1}{c}{. } \\
Female & 0.5172 & 0.5004 & 0 & 1 & 0.4949 \\
Bachelor's degree or higher & 0.5449 & 0.4986 & 0 & 1 & 0.1308 \\
White & 0.8196 & 0.3850 & 0 & 1 & 0.6373 \\
Asian & 0.0557 & 0.2297 & 0 & 1 & 0.1714 \\
Black or African American & 0.0106 & 0.1025 & 0 & 1 & 0.0569 \\
American Indian or Alaska & 0.0133 & 0.1145 & 0 & 1 & 0.0133 \\
$\quad$ Native & & & & & \\
From multiple races & 0.0239 & 0.1528 & 0 & 1 & 0.0548 \\
From other race & 0.0106 & 0.1026 & 0 & 1 & 0.0561 \\
Prefer not to answer & 0.0663 & 0.2491 & 0 & 1 & - \\
Hispanic or Latino & 0.0476 & 0.2132 & 0 & 1 & 0.1639 \\
Income (\$) & 72,139 & 42,686 & 15,000 & 250,000 & 47,647 \\
Employed full time & 0.5397 & 0.4991 & 0 & 1 & 0.2964 \\
Year house built & 1958 & 28.69 & 1903 & 2017 & - \\
Lot square footage & 8,382 & 6,527 & 468 & 64,051 & - \\
Building square footage & $1,370.18$ & 552.41 & 528 & 3,548 & - \\
Total assessed value (\$) & 280,012 & 72,418 & 159,190 & 807,250 & - \\
Euclidean distance to Johnson & 4,078 & 2,421 & 304 & 10,948 & - \\
$\quad$ Creek (ft.) & & & & & \\
\hline
\end{tabular}

and those outside the 100-year floodplain were asked to consider their maximum annual WTP if they were to live in the 100-year floodplain. Respondents selected from 11 dollar amounts ranging from $\$ 0$ to "More than $\$ 3,000$ " or "I don't know." A respondent with a maximum WTP between two amounts, for example, $\$ 350$ and $\$ 550$ should select the smaller amount (see Appendix B). Because all respondents were asked to report their maximum annual WTP for flood insurance inside the 100-year floodplain, differences in WTP based on where they actually reside could indicate variations in knowledge, understanding, or risk preferences across these groups. Table 2 shows the breakdown of maximum annual WTP values for the survey responses used in our models.

The 50 respondents that selected the "I don't know" WTP option are not included in our models. Of the 38 respondents who selected $\$ 0$ maximum annual WTP, $82 \%$ stated in a follow-up question that they thought flooding and property damage were unlikely to occur, which is consistent with McClelland, Schulze, and Coursey's (1993) insurance market experiment that found a bimodal distribution-with many individuals bidding either
Table 2

Annual Willingness to Pay

\begin{tabular}{lcc}
\hline $\begin{array}{l}\text { Annual Willingness } \\
\text { to Pay }\end{array}$ & $\begin{array}{c}\text { Number of } \\
\text { Respondents }\end{array}$ & Percentage \\
\hline$\$ 0$ & 38 & 13.62 \\
$\$ 100$ & 43 & 15.41 \\
$\$ 150$ & 24 & 8.60 \\
$\$ 250$ & 38 & 13.62 \\
$\$ 350$ & 39 & 13.98 \\
$\$ 550$ & 46 & 16.49 \\
$\$ 850$ & 14 & 5.02 \\
$\$ 1,250$ & 27 & 9.68 \\
$\$ 2,000$ & 7 & 2.51 \\
$\$ 3,000$ & 1 & 0.36 \\
More than $\$ 3,000$ & 2 & 0.72 \\
\hline Note: $N=279$. & &
\end{tabular}

Note: $N=279$.

zero or much more than the expected valuefor a low-probability event. Flood insurance was not worth it for $18 \%$ of responses, $11 \%$ stated they couldn't afford to pay for flood insurance, $16 \%$ had other more important priorities, and $8 \%$ felt that it was unfair to expect them to pay for flood insurance. ${ }^{12}$ Botzen and van den Bergh (2012) report a much

\footnotetext{
${ }^{12}$ Respondents could select multiple reasons they had $\$ 0$ WTP, which is why the sum of possible responses exceeds $100 \%$.
} 
higher percentage of respondents expressing \$0 WTP ranging from $49.2 \%$ for a $1-$ in- 400 flood probability to $75.8 \%$ for a 1 -in-1,250 flood probability. Thirty-seven percent of respondents in Roder, Hudson, and Tarolli's (2019) study failed to answer or wrote in $\$ 0$ WTP for the flood insurance policy described in their survey; in our study, the percentage of "I don't know" and \$0 WTP responses is only about $27 \%$, perhaps reflecting greater familiarization with this issue among our sample.

The explanatory variables used in our models and their hypothesized signs are presented in Table 3. Our predictors of WTP are drawn from prior studies, our knowledge of flood insurance demand, and our familiarity with this study area. We expect measures of objective risk, such as a property's location in the 100-year floodplain, location in an AE or $\mathrm{AH}$ flood zone, and the volume of expected flooding during a 100-year flood event, to have a positive effect on WTP compared with the excluded category of properties outside a floodplain. We are uncertain about the expected sign for properties with a building footprint in the 500-year floodplain. Although these properties are at increased risk of flooding compared with those outside the 100-year or 500-year floodplain, homeowners are often unaware that they are at risk because there is no disclosure requirement for these properties. As such, they do not receive as much information from government agencies-federal or local-on flooding and insurance as those in the 100-year floodplain.

We expect subjective flood risk, captured by the respondent's assessment of their current home's flood risk compared to their neighborhood, to increase WTP for the highest two levels compared to the excluded "I don't know" category (Botzen and van den Bergh 2012; Seifert et al. 2013). We are uncertain about the expected signs for the other risk categories.

Expected future basement or crawlspace flooding, another question about risk perceptions on the survey, should increase a respondent's WTP, but we are uncertain about the sign for respondents who experienced flood damages. The highest crest ever recorded in the study area occurred in December 2015 (National Oceanic and Atmospheric Ad- ministration 2019), so if respondents draw on this recent flood event as a reminder of flood risk (Browne and Hoyt 1999; Dixon et al. 2006), we would expect a positive effect on WTP, but if respondents believe that the chance of a flooding has declined, the socalled gambler's fallacy, the expected effect on WTP would be negative (Kunreuther and Michel-Kerjan 2015). We list this effect as uncertain in Table 3.

Home characteristics may influence a respondent's WTP. We are uncertain about sign if a respondent has a basement or crawlspace (compared to neither). On the one hand, shallow flooding is more likely to affect homes with basements, potentially increasing the WTP for insurance; on the other hand, NFIP coverage in basements is much more limited, suggesting a lower WTP for a NFIP policy if only basement inundation is of concern. Botzen and van den Bergh (2012) found that distance from the water body decreased WTP, whereas Brody et al. (2017) found that proximity to a flood hazard area did not affect the decision to purchase flood insurance. Exploring the relationship between WTP and distance to Johnson Creek is especially interesting in our study area because the majority of the 100-year floodplain is not close to Johnson Creek (Figure 1b). We expect a negative sign for that coefficient if respondents use distance to the water body as a heuristic for flood risk.

Demographic factors are included in the model with income being the primary variable of interest. We expect a positive coefficient for the income variable based on other research that explores WTP for flood insurance and income (Kriesel and Landry 2004; Botzen and van den Bergh 2012; Atreya, Ferreira, and Michel-Kerjan 2015). Previous research has found a positive relationship between the adoption of flood insurance and the participant's level of education (Atreya, Ferreira, and Michel-Kerjan 2015), so we hypothesize a similar relationship for WTP. There are conflicting findings in the literature about age (Dohmen et al. 2011; Botzen and van den Bergh 2012), so we are uncertain about the expected sign for that variable. 
Table 3

Summary Statistics for Explanatory Variables

\begin{tabular}{|c|c|c|c|c|c|}
\hline Variable & Description and Units & $\begin{array}{l}\text { Expected } \\
\text { Sign }\end{array}$ & Average & $\begin{array}{l}\text { Standard } \\
\text { Deviation }\end{array}$ & $\begin{array}{l}\text { Count When } \\
\text { Variable }=1\end{array}$ \\
\hline \multicolumn{6}{|l|}{ Objective Risk Measures } \\
\hline In 100-year floodplain & $\begin{array}{l}=1 \text { building footprint in } 100 \text {-year } \\
\text { floodplain } \\
=0 \text { otherwise }\end{array}$ & + & 0.2509 & 0.4343 & 70 \\
\hline AE zone & $\begin{array}{l}=1 \text { building footprint in } \mathrm{AE} \text { flood } \\
\text { zone } \\
=0 \text { otherwise }\end{array}$ & + & 0.0287 & 0.1672 & 8 \\
\hline AH zone & $\begin{array}{l}=1 \text { building footprint in } \mathrm{AH} \text { flood } \\
\text { zone } \\
=0 \text { otherwise }\end{array}$ & + & 0.2222 & 0.4165 & 62 \\
\hline In 500-year floodplain & $\begin{array}{l}=1 \text { if building footprint in } 500 \text {-year } \\
\text { floodplain } \\
=0 \text { otherwise }\end{array}$ & $?$ & 0.0717 & 0.2584 & 20 \\
\hline $\begin{array}{l}\text { Outside floodplain } \\
\quad \text { (excluded) }\end{array}$ & $\begin{array}{l}=1 \text { if building footprint is outside a } \\
\text { floodplain } \\
=0 \text { otherwise }\end{array}$ & N/A & 0.6774 & 0.4683 & 189 \\
\hline $\begin{array}{l}\text { Volume of expected } \\
\text { flooding }\end{array}$ & $\begin{array}{l}\text { Volume of expected flooding in } \\
\text { primary structure }\left(1,000 \mathrm{ft.}^{3}\right)\end{array}$ & + & 0.2371 & 0.9751 & N/A \\
\hline \multicolumn{6}{|c|}{ Subjective Flood Risk and Flood Experience } \\
\hline Experienced flood damage & $\begin{array}{l}=1 \text { if any flood damage reported } \\
=0 \text { otherwise }\end{array}$ & $?$ & 0.0932 & 0.2912 & 38 \\
\hline $\begin{array}{l}\text { Zero expected future } \\
\quad \text { flooding (excluded) }\end{array}$ & $\begin{array}{l}=1 \text { if expected frequency of basement } \\
\text { flooding is } 0 \\
=0 \text { otherwise }\end{array}$ & N/A & 0.7168 & 0.4513 & 200 \\
\hline $\begin{array}{l}\text { 1-2 times expected future } \\
\text { flooding }\end{array}$ & $\begin{array}{l}=1 \text { if expected frequency of basement } \\
\text { flooding is } 1-2 \text { times } \\
=0 \text { otherwise }\end{array}$ & + & 0.2258 & 0.4189 & 63 \\
\hline $\begin{array}{l}3 \text { or more times expected } \\
\text { future flooding }\end{array}$ & $\begin{array}{l}=1 \text { if expected frequency of basement } \\
\text { flooding is } 3 \text { or more times } \\
=0 \text { otherwise }\end{array}$ & + & 0.0573 & 0.2329 & 16 \\
\hline $\begin{array}{l}\text { Home's risk much lower } \\
\text { than neighborhood }\end{array}$ & $\begin{array}{l}=1 \text { if home's risk is much lower than } \\
\text { neighborhood } \\
=0 \text { otherwise }\end{array}$ & $?$ & 0.3692 & 0.4834 & 102 \\
\hline $\begin{array}{l}\text { Home's risk somewhat } \\
\text { lower than neighborhood }\end{array}$ & $\begin{array}{l}=1 \text { if home's risk is somewhat lower } \\
\text { than neighborhood } \\
=0 \text { otherwise }\end{array}$ & $?$ & 0.2366 & 0.4257 & 65 \\
\hline $\begin{array}{l}\text { Home's risk average for } \\
\text { neighborhood }\end{array}$ & $\begin{array}{l}=1 \text { if home's risk is average for } \\
\text { neighborhood } \\
=0 \text { otherwise }\end{array}$ & $?$ & 0.1935 & 0.3958 & 54 \\
\hline $\begin{array}{l}\text { Home's risk somewhat } \\
\text { higher than } \\
\text { neighborhood }\end{array}$ & $\begin{array}{l}=1 \text { if home's risk is somewhat higher } \\
\text { than neighborhood } \\
=0 \text { otherwise }\end{array}$ & + & 0.0466 & 0.2111 & 13 \\
\hline $\begin{array}{l}\text { Home's risk much higher } \\
\text { than neighborhood }\end{array}$ & $\begin{array}{l}=1 \text { if home's risk is much higher than } \\
\text { neighborhood } \\
=0 \text { otherwise }\end{array}$ & + & 0.0108 & 0.1033 & 3 \\
\hline $\begin{array}{l}\text { Don't know home's } \\
\text { risk compared to } \\
\text { neighborhood (excluded) }\end{array}$ & $\begin{array}{l}=1 \text { if respondent selected "don't } \\
\text { know" for home's risk } \\
=0 \text { otherwise }\end{array}$ & N/A & 0.1434 & 0.3511 & 40 \\
\hline \multicolumn{6}{|l|}{ Home Characteristics } \\
\hline Mortgage & $\begin{array}{l}=1 \text { if property has a mortgage } \\
=0 \text { otherwise }\end{array}$ & $?$ & 0.7849 & 0.4116 & 219 \\
\hline $\begin{array}{l}\text { Property has a basement } \\
\text { and/or crawlspace }\end{array}$ & $\begin{array}{l}=1 \text { if property has a basement and/or } \\
\text { crawlspace } \\
=0 \text { otherwise }\end{array}$ & $?$ & 0.9534 & 0.2111 & 266 \\
\hline
\end{tabular}


Table 3

Summary Statistics for Explanatory Variables (continued)

\begin{tabular}{|c|c|c|c|c|c|}
\hline Variable & Description and Units & $\begin{array}{l}\text { Expected } \\
\text { Sign }\end{array}$ & Average & $\begin{array}{l}\text { Standard } \\
\text { Deviation }\end{array}$ & $\begin{array}{l}\text { Count When } \\
\text { Variable }=1\end{array}$ \\
\hline Property's total value & $\begin{array}{l}\text { Total assessed property value } \$ 10,000 \\
\text { (2017) }\end{array}$ & + & 28.2143 & 6.8772 & N/A \\
\hline In FEMA map error area & $\begin{array}{l}=1 \text { if property in FEMA map error } \\
\text { area } \\
=0 \text { otherwise }\end{array}$ & - & 0.1470 & 0.3547 & 41 \\
\hline Distance to Johnson Creek & $\begin{array}{l}\text { Euclidean distance to Johnson Creek } \\
\text { (ft.) }\end{array}$ & - & 4,121 & 2,458 & N/A \\
\hline \multicolumn{6}{|l|}{ Demographics } \\
\hline Income & Midpoint of income categories (\$) & + & 73,952 & 43,551 & N/A \\
\hline Education & $\begin{array}{l}=1 \text { if bachelor's degree or higher } \\
=0 \text { otherwise }\end{array}$ & + & 0.5806 & 0.4943 & 162 \\
\hline White (excluded) & $\begin{array}{l}=1 \text { if White } \\
=0 \text { otherwise }\end{array}$ & N/A & 0.8495 & 0.3582 & 237 \\
\hline Asian & $\begin{array}{l}=1 \text { if Asian } \\
=0 \text { otherwise }\end{array}$ & $?$ & 0.0538 & 0.2260 & 15 \\
\hline Prefer not to answer & $\begin{array}{l}=1 \text { if "prefer not to answer" } \\
=0 \text { otherwise }\end{array}$ & $?$ & 0.0430 & 0.2032 & 12 \\
\hline Other & $\begin{aligned} &= 1 \text { if Black or African American, } \\
& \text { American Indian or Alaska Native, } \\
& \text { Native Hawaiian or other Pacific } \\
& \text { Islander, some other race, or from } \\
& \text { multiple races } \\
&=0 \text { otherwise }\end{aligned}$ & $?$ & 0.0538 & 0.2260 & 15 \\
\hline Age & Years & $?$ & 50.76 & 15.25 & N/A \\
\hline Male (excluded) & $\begin{array}{l}=1 \text { if male } \\
=0 \text { otherwise }\end{array}$ & N/A & 0.4516 & 0.4985 & 126 \\
\hline Female & $\begin{array}{l}=1 \text { if female } \\
=0 \text { otherwise }\end{array}$ & $?$ & 0.5232 & 0.5004 & 146 \\
\hline $\begin{array}{l}\text { Nonbinary or prefer not to } \\
\text { answer }\end{array}$ & $\begin{array}{l}=1 \text { if nonbinary or PNTA } \\
=0 \text { otherwise }\end{array}$ & $?$ & 0.0251 & 0.1567 & 7 \\
\hline $\begin{array}{l}\text { Tenancy less than } 1 \text { year } \\
\text { (excluded) }\end{array}$ & $\begin{array}{l}=1 \text { if less than } 1 \text { year } \\
=0 \text { otherwise }\end{array}$ & N/A & 0.0932 & 0.2912 & 26 \\
\hline Tenancy of $1-3$ years & $\begin{array}{l}=1 \text { if tenancy of } 1-3 \text { years } \\
=0 \text { otherwise }\end{array}$ & $?$ & 0.2151 & 0.4116 & 60 \\
\hline Tenancy of 4-7 years & $\begin{array}{l}=1 \text { if tenancy of } 4-7 \text { years } \\
=0 \text { otherwise }\end{array}$ & $?$ & 0.1792 & 0.3842 & 50 \\
\hline Tenancy of $8-15$ years & $\begin{array}{l}=1 \text { if tenancy of } 8-15 \text { years } \\
=0 \text { otherwise }\end{array}$ & $?$ & 0.2079 & 0.4065 & 58 \\
\hline $\begin{array}{l}\text { Tenancy of more than } 15 \\
\text { years }\end{array}$ & $\begin{array}{l}=1 \text { if tenancy of more than } 15 \text { years } \\
=0 \text { otherwise }\end{array}$ & $?$ & 0.3047 & 0.4611 & 85 \\
\hline
\end{tabular}

Note: $N=279$.

\section{Regression Models and Results}

Flood insurance is a marketed good, so it is reasonable to assume that all respondents are willing to pay some amount of money for the flood insurance policy described in our WTP question (Appendix B). This makes our use of contingent valuation different from applications in the nonmarket valuation literature, where it is reasonable to assume that respondents have a true \$0 WTP.
There are several options for estimating determinants of annual WTP to account for censoring our dependent variable including interval Tobit using a normal or Weibull distribution (Carson et al. 1992; Wooldridge 2019; StataCorp 2019a, 2019b), a double-hurdle model such as the Cragg (Cragg 1971; Burke 2009), or a Poisson or negative binomial model. We tested these models and found the interval Tobit model (normal distribution) had the best fit to the data. Those results are 
included in Table 4 with predicted WTP values based on the interval Tobit (Weibull distribution) model given in Appendix C. ${ }^{13}$ The Cragg, Poisson, and negative binomial models had a much poorer fit than the interval Tobit models, so we do not report those results.

The interval Tobit models use the log of the lower and upper bounds of the annual WTP values as the dependent variable. Independent variables, listed in Table 3 , include objective risk measures, subjective risk, and flood experience variables, as well as home and demographic characteristics. Objective risk measures vary by model with model 1 using a property's location (based on building footprint) in the 100- or 500-year floodplain, model 2 using the AE or AH flood zones, and model 3 using the projected flood volume $\left(1,000\right.$ s of $\left.^{2} .^{3}\right)$ inside a building during a 100year event. Results are presented in Table 4; the estimated coefficients are average marginal effects.

Respondents with a property inside or intersected by the 100-year floodplain (model 1) are estimated to be willing to pay about $69 \%$ more for flood insurance than respondents who live outside the 100 - or 500-year floodplains. In model 2, survey respondents who live in flood zones $\mathrm{AE}$ or $\mathrm{AH}$ are predicted to have a significantly higher annual WTParound $108 \%$ higher for $\mathrm{AE}$ and $60 \%$ higher for $\mathrm{AH}$ - than respondents who live outside floodplain areas. Given the possibility of deeper flood waters, and thus more significant damage, the magnitude of the coefficient on the $\mathrm{AE}$ zone variable exceeds the $\mathrm{AH}$ zone variable, as would be expected, although the estimated coefficients are not significantly different from each other ( $p$-value 0.167). This could be due to the small number of respondents in our sample that have properties in the AE zone. In neither model 1 nor model 2 is the estimated coefficient on the 500-year floodplain variable significant. This is not surprising because there is no requirement in this

\footnotetext{
${ }^{13}$ We ran an ordinary least squares (OLS) model using the natural log of the lower bound of the WTP value as the dependent variable. We lose observations (279 to 241 ) because respondents who selected $\$ 0$ drop out of the model. Key findings from the interval Tobit model hold in the OLS model.
}

area to purchase flood insurance, and there is no required disclosure about flood risk when properties in the 500-year floodplain are sold. As such, those in the 500-year floodplain probably have similar information and education as those outside either the 100-year or 500-year floodplains. Model 3, which uses the expected volume of water inside a building during a 100-year event as the objective risk measure, also has a significantly positive WTP with each additional $1,000 \mathrm{ft}^{3}$ of water in a building increasing estimated WTP by $14.63 \%$. This measure more accurately captures the potential for property damage, and we find that annual WTP is indeed responsive to the improved measure.

Surprisingly, self-reported prior experiences with flood damage are not statistically significant-perhaps because it had been several years since the last flood (National Oceanic and Atmospheric Administration 2019). We may also fail to find significance if respondents who care less about flooding are more likely to live in riskier areas-that is, those who are most likely to have experienced a flood are also least likely to be concerned about it. In contrast to prior experience, some flood-risk perception variables are significant. ${ }^{14}$ Respondents who viewed their current home's flood risk as being somewhat higher than their neighborhood's risk had about a $40 \%$ higher annual WTP than respondents who selected "I don't know." This increases to $120 \%$ for respondents who believe their home's risk of flooding is much higher than that of their neighborhood. A positive expected frequency of basement or crawlspace flooding in the next 30 years, compared with the excluded category of no expected basement or crawlspace flooding, was also significantly positive in influencing WTP in all models, but we fail to reject the hypothesis of equal estimated effects for respondents who expect flooding one or two times, or three or more times.

Structural characteristics of the house were never statistically significant predictors of

\footnotetext{
${ }^{14}$ Note that the correlations between our measures of flood risk are never greater than 0.43 and usually substantially lower than this.
} 
Table 4

Interval Tobit Regression Results

\begin{tabular}{|c|c|c|c|}
\hline & $\begin{array}{l}\text { Model } 1 \\
\text { Floodplain }\end{array}$ & $\begin{array}{c}\text { Model } 2 \mathrm{AE} \text { and } \\
\text { AH Zones }\end{array}$ & $\begin{array}{l}\text { Model } 3 \\
\text { Volume }\end{array}$ \\
\hline In 100-year floodplain & $\begin{array}{l}0.6897 * * * \\
(0.1975)\end{array}$ & & \\
\hline AE zone & & $\begin{array}{l}1.0792 * * * \\
(0.3212)\end{array}$ & \\
\hline AH zone & & $\begin{array}{l}0.5963 * * * \\
(0.2173)\end{array}$ & \\
\hline In 500-year floodplain & $\begin{array}{c}-0.2655 \\
(0.2581)\end{array}$ & $\begin{array}{c}-0.2623 \\
(0.2579)\end{array}$ & \\
\hline Volume of expected flooding & & & $\begin{array}{l}0.1463 * * * \\
(0.0386)\end{array}$ \\
\hline Experienced flood damage & $\begin{array}{l}-0.1696 \\
(0.2272)\end{array}$ & $\begin{array}{l}-0.1546 \\
(0.2284)\end{array}$ & $\begin{array}{c}-0.1351 \\
(0.2289)\end{array}$ \\
\hline 1-2 times expected future flooding & $\begin{array}{l}0.4426^{* * * *} \\
(0.1377)\end{array}$ & $\begin{array}{l}0.4590 * * * \\
(0.1376)\end{array}$ & $\begin{array}{l}0.4503 * * * \\
(0.1412)\end{array}$ \\
\hline 3 or more times expected future flooding & $\begin{array}{l}0.4300 * * \\
(0.1804)\end{array}$ & $\begin{array}{l}0.4355^{* *} \\
(0.1809)\end{array}$ & $\begin{array}{l}0.4082 * * \\
(0.1825)\end{array}$ \\
\hline Home's risk much lower than neighborhood & $\begin{array}{c}0.2195 \\
(0.1915)\end{array}$ & $\begin{array}{c}0.2306 \\
(0.1910)\end{array}$ & $\begin{array}{c}0.2773 \\
(0.1906)\end{array}$ \\
\hline $\begin{array}{l}\text { Home's risk somewhat lower than } \\
\text { neighborhood }\end{array}$ & $\begin{array}{c}0.2953 \\
(0.1894)\end{array}$ & $\begin{array}{c}0.2947 \\
(0.1879)\end{array}$ & $\begin{array}{c}0.3065 \\
(0.1930)\end{array}$ \\
\hline Home's risk average for neighborhood & $\begin{array}{c}0.3336 \\
(0.2034)\end{array}$ & $\begin{array}{r}0.3398 * \\
(0.2034)\end{array}$ & $\begin{array}{c}0.3664 * \\
(0.1974)\end{array}$ \\
\hline $\begin{array}{l}\text { Home's risk somewhat higher than } \\
\text { neighborhood }\end{array}$ & $\begin{array}{r}0.3961^{*} \\
(0.2195)\end{array}$ & $\begin{array}{l}0.4052^{*} \\
(0.2211)\end{array}$ & $\begin{array}{r}0.4488^{*} \\
(0.2326)\end{array}$ \\
\hline Home's risk much higher than neighborhood & $\begin{array}{l}1.2012 * * * \\
(0.4632)\end{array}$ & $\begin{array}{l}0.9923 * * \\
(0.4205)\end{array}$ & $\begin{array}{l}1.6243 * * * \\
(0.5588)\end{array}$ \\
\hline Mortgage & $\begin{array}{c}0.1745 \\
(0.1704)\end{array}$ & $\begin{array}{c}0.1779 \\
(0.1701)\end{array}$ & $\begin{array}{c}0.1756 \\
(0.1685)\end{array}$ \\
\hline Property has a basement and/or crawlspace & $\begin{array}{c}-0.0957 \\
(0.2155)\end{array}$ & $\begin{array}{c}-0.0891 \\
(0.2157)\end{array}$ & $\begin{array}{c}-0.0592 \\
(0.2255)\end{array}$ \\
\hline Property's total value & $\begin{array}{l}-0.0067 \\
(0.0099)\end{array}$ & $\begin{array}{l}-0.0070 \\
(0.0099)\end{array}$ & $\begin{array}{l}-0.0090 \\
(0.0107)\end{array}$ \\
\hline In FEMA map error area & $\begin{array}{c}-0.4284 * \\
(0.2326)\end{array}$ & $\begin{array}{c}-0.3138 \\
(0.2602)\end{array}$ & $\begin{array}{c}0.1312 \\
(0.1869)\end{array}$ \\
\hline Log Euclidean distance to Johnson Creek & $\begin{array}{c}-0.0455 \\
(0.0743)\end{array}$ & $\begin{array}{c}-0.0160 \\
(0.0825)\end{array}$ & $\begin{array}{c}-0.1208^{*} \\
(0.0710)\end{array}$ \\
\hline Natural log of income & $\begin{array}{l}0.3087 * * \\
(0.1203)\end{array}$ & $\begin{array}{l}0.3107 * * \\
(0.1206)\end{array}$ & $\begin{array}{l}0.3519 * * * \\
(0.1240)\end{array}$ \\
\hline Education & $\begin{array}{c}0.0648 \\
(0.1405)\end{array}$ & $\begin{array}{c}0.0559 \\
(0.1406)\end{array}$ & $\begin{array}{c}0.0225 \\
(0.1399)\end{array}$ \\
\hline Asian & $\begin{array}{c}-0.4576^{* *} \\
(0.2157)\end{array}$ & $\begin{array}{c}-0.4664 * * \\
(0.2167)\end{array}$ & $\begin{array}{c}-0.4969 * * \\
(0.2137)\end{array}$ \\
\hline Race is "prefer not to answer" & $\begin{array}{c}-0.5869 * * \\
(0.2528)\end{array}$ & $\begin{array}{c}-0.5937 * * \\
(0.2534)\end{array}$ & $\begin{array}{c}-0.6078 * * \\
(0.2607)\end{array}$ \\
\hline Race is "other" & $\begin{array}{c}0.0793 \\
(0.3042)\end{array}$ & $\begin{array}{c}0.0837 \\
(0.3068)\end{array}$ & $\begin{array}{c}0.0502 \\
(0.3159)\end{array}$ \\
\hline Respondent's age & $\begin{array}{c}0.0025 \\
(0.0055)\end{array}$ & $\begin{array}{c}0.0031 \\
(0.0055)\end{array}$ & $\begin{array}{c}0.0026 \\
(0.0055)\end{array}$ \\
\hline Female & $\begin{array}{c}-0.0769 \\
(0.1229)\end{array}$ & $\begin{array}{c}-0.0779 \\
(0.1225)\end{array}$ & $\begin{array}{c}-0.0272 \\
(0.1225)\end{array}$ \\
\hline Gender is nonbinary or prefer not to answer & $\begin{array}{c}0.3435 \\
(0.4846)\end{array}$ & $\begin{array}{c}0.3764 \\
(0.4853)\end{array}$ & $\begin{array}{c}0.2816 \\
(0.5087)\end{array}$ \\
\hline Tenancy of $1-3$ years & $\begin{array}{c}0.0844 \\
(0.2213)\end{array}$ & $\begin{array}{c}0.0810 \\
(0.2228)\end{array}$ & $\begin{array}{c}0.0082 \\
(0.2255)\end{array}$ \\
\hline
\end{tabular}


Table 4

Interval Tobit Regression Results (cotinued)

\begin{tabular}{lccc}
\hline & Model 1 & Model 2 AE and & Model 3 \\
& Floodplain & AH Zones & Volume \\
\hline Tenancy of 4-7 years & -0.1873 & -0.1965 & -0.2408 \\
& $(0.2150)$ & $(0.2162)$ & $(0.2206)$ \\
Tenancy of 8-15 years & -0.0665 & -0.0654 & -0.1473 \\
& $(0.2341)$ & $(0.2348)$ & $(0.2372)$ \\
Tenancy of more than 15 years & $-0.4664^{*}$ & $-0.4857^{*}$ & $-0.5136^{* *}$ \\
& $(0.2490)$ & $(0.2492)$ & $(0.2515)$ \\
Constant & $2.8613^{*}$ & $2.6140^{*}$ & $2.9759^{* *}$ \\
& $(1.5133)$ & $(1.5511)$ & $(1.5106)$ \\
Observations & 279 & 279 & 279 \\
Log likelihood & -572.21 & -571.66 & -575.64 \\
AIC & $1,202.42$ & $1,203.32$ & $1,207.28$ \\
BIC & $1,307.73$ & $1,312.26$ & $1,308.96$ \\
\hline$\quad$ Note: Robust standard errors in parentheses. & & & \\
${ }^{*} p<0.10 ;{ }^{* *} p<0.05 ;{ }^{* * *} p<0.01$. & & &
\end{tabular}

WTP. ${ }^{15}$ It is perhaps surprising that there was not a positive and significant coefficient on building value because higher-valued homes would need to purchase higher levels of coverage for the same financial protection, and this would cost more. ${ }^{16}$ We did find that being in the FEMA map error location lowered WTP in model 1. Although respondents in the 100year floodplain are estimated to have a $69 \%$ higher annual WTP than respondents outside any floodplain in this model, the annual WTP for respondents in the FEMA map error area is only $26 \%$ higher than respondents outside any floodplain. ${ }^{17}$ The FEMA map error area variable was not statistically significant in models 2 and 3 . The effect of distance from Johnson Creek is negative in all models, but only significant in model 3 , where a $1 \%$ increase in distance from Johnson Creek is estimated to decrease WTP by $0.12 \%$. Although the location of the floodplain can be as far as a mile from Johnson Creek (Figure 1), the lack of significance for this variable in models 1

\footnotetext{
${ }^{15}$ One possible explanation for why structural characteristics are insignificant is if home values are correlated with subjective flood risk. The correlation between total building value and respondents' assessments of their current home's flood risk compared with their neighborhood, however, is only weakly negative $(-0.1073)$.

${ }^{16}$ Median building coverage in our study area for single-family policies in the 100 -year floodplain is $\$ 175,500$.

${ }^{17}$ Respondents in the FEMA map error area are also in the 100-year floodplain. The estimated effect is the sum of the "In 100-year floodplain" and "In FEMA map error area" coefficients.
}

and 2 may be attributable to collinearity with the floodplain location variables.

Personal characteristics of the respondent are more predictive. Respondent's income is significantly positive in all models with estimated elasticities of between 0.31 and 0.35 across all three models. Respondents who self-identified as Asian have a roughly $46 \%$ to $50 \%$ lower WTP than do white residents. The estimated effect for individuals who selected "prefer not to answer" for the race variable is even larger, with a lower WTP of $58.69 \%$ (model 1), 59.37\% (model 2), and 60.78\% (model 3). Surname and location information have been used by some researchers to predict race and ethnicity (Imai and Khanna 2016; Shah and Davis 2017; Crabtree and Chykina 2018; Henninger, Meredith, and Morse 2018). Using the R package wru (Khanna and Imai 2019), we predict that about half of the respondents who selected "prefer not to answer" are nonwhite.

The effect of tenancy of 15 years or more is significantly negative compared to the excluded category, which is tenancy of less than one year. Unfortunately, we are not able to identify the mechanism driving this result, but there are several plausible hypotheses. The first is learning and experience: residents who have lived a long time in the neighborhood and have not experienced substantial flood-related damage are willing to pay less for flood insurance because they believe they are at lower risk. Second, there could be a selection 
Table 5

Summary Statistics for Predicted Annual Willing to Pay

\begin{tabular}{lccc}
\hline & Model 1 Floodplain & Model 2 AE and AH Zones & Model 3 Volume \\
\hline $\begin{array}{l}\text { All Respondents }(N=279) \\
\text { Mean }\end{array}$ & & \\
Median & $\$ 391.44$ & $\$ 393.35$ & $\$ 385.28$ \\
Standard deviation & $\$ 324.21$ & $\$ 320.35$ & $\$ 327.31$ \\
Respondents in 100-Year Floodplain $(N=70)$ & $\$ 313.97$ & \\
Mean & $\$ 297.19$ & & \\
Median & $\$ 513.48$ & $\$ 620.06$ & \\
Standard deviation & $\$ 461.91$ & $\$ 513.90$ & $\$ 538.95$ \\
Respondents Outside 100-Year Floodplain $(N=209)$ & & $\$ 437.90$ \\
Mean & $\$ 317.07$ & $\$ 317.42$ & \\
Median & $\$ 280.61$ & $\$ 277.20$ & $\$ 333.82$ \\
Standard deviation & $\$ 158.57$ & $\$ 160.45$ & $\$ 296.13$ \\
\hline
\end{tabular}

effect, in that homeowners who have lived in the neighborhood longer than 15 years may have reasons they are unable to move elsewhere, such as income constraints, that also translate into a lower ability to pay for flood insurance.

Predicted means and median annual WTP for the three models are reported in Table 5 for all respondents, and then separately for respondents with properties that have building footprints inside or intersected by the 100year floodplain from those with properties outside the 100-year floodplain. ${ }^{18} \mathrm{~A}$ test of means firmly rejects the hypothesis of equal mean WTP for those respondents inside and outside the 100-year floodplain ( $p$-value $=$ 0.00 ). A test of means across models found that the mean WTP estimates for respondents inside the 100-year floodplain are not statistically different from each other; we reached the same conclusion for respondents outside the 100-year floodplain.

Respondents inside and outside the 100year floodplain were presented with the same valuation scenario of a one in four chance of their home flooding with 1-3 ft. of water over the life of a 30-year mortgage (Appendix B). The difference in predicted annual WTP for

\footnotetext{
${ }^{18}$ WTP estimates using the interval Tobit (Weibull distribution) are in Appendix Table C2. Estimates are comparable with those reported in Table 5, for example, median annual WTP for respondents who live in the 100-year floodplain are $\$ 496.69$ (model 1), \$505.63 (model 2), and \$454.86 (model $3)$.
}

respondents in the 100-year floodplain may be a result of greater knowledge about flood risks for 100-year floodplain residents due to the city's extensive outreach efforts as part of FEMA's CRS.

Another possible explanation for why 100year floodplain respondents have a higher WTP is that they are anchoring on self-reported flood insurance payments (Ariely, Loewenstein, and Prelec 2003). For example, a respondent with a current flood insurance premium of $\$ 1,000$, who exhibited an anchoring bias, would state a maximum WTP of $\$ 850$ based on the possible payment card values (Appendix B). However, of the 50 respondents with self-reported flood insurance premiums, $30 \%$ selected a higher value and $44 \%$ selected a lower value than what they currently paid for flood insurance. In other words, the vast majority of respondents (74\%) did not anchor on their self-reported flood insurance premiums.

\section{Conclusions and Policy Implications}

Our study focuses on two highly urbanized neighborhoods in Portland, Oregon, that are susceptible to flooding. In many ways, our study area is facing similar flood risk management challenges as other communities around the country. Changes in the frequency, timing, and intensity of storms because of climate 
change are predicted to cause more flooding in many places. Urban centers face greater flood risk from intense precipitation events that overwhelm local drainage systems (National Academies of Sciences, Engineering, and Medicine 2019). These changes can be exacerbated by population growth, increased development, and decreases in natural areas that could help mitigate flooding. Given these common threats, our work in Portland has broader implications.

As stated earlier, insurance is a critical recovery tool for these increasing disasters. Our article presents the first WTP estimates for flood insurance for a study area in the United States. In the United States, homeowners in a mapped 100-year floodplain are required to purchase flood insurance if they have a loan from a federally backed or regulated lender. In 2011-2015, an estimated $10 \%$ of the U.S. population lived in a 100 - or 500-year floodplain, with $15 \%$ of 100 -year floodplain residents classified as living in poverty (Peri, Rosoff, and Yager 2017). Estimates for our study area, with a higher poverty rate at $23 \%$, predict a median annual WTP of between $\$ 414$ and \$514.

We find that WTP is higher, as expected, with higher objective flood risk and with greater perceptions of flood risk. This is probably a combination of greater value of insurance in areas of higher risk and greater risk awareness and understanding in higher risk areas, particularly SFHAs. Given the insurance and property disclosure requirements in these areas, residents may be more aware of the benefits of flood insurance. It should be noted that the NFIP is currently updating their rating using modern catastrophe models to better reflect property-level flood risk. When implemented in 2021, flood insurance premiums will be more tightly linked to objective flood risk.

Flood awareness may vary not just by actual risk but by other demographic factors. For instance, we find a significantly negative association between WTP and respondents who self-identified as Asian or selected "prefer not to answer"; this could provide additional support for Atreya, Ferreira, and Michel-Kerjan's (2015) suggestion that FEMA information campaigns target audiences by demographic factors or to prioritize reaching all communities in outreach and education campaigns.

For many respondents, their stated WTP is well below the actual cost of flood insurance in the 100-year floodplain, highlighting a challenge to improving financial resilience to flood events. The median cost of flood insurance in the ZIP code that covers the majority of the study area was $\$ 878$ in 2018 (FEMA 2019), which included a $20 \%$ subsidy because, at the time of our study, Portland had a class 6 rating in the CRS. The median annual WTP for respondents in the 100-year floodplain ranges from roughly $47 \%$ to $59 \%$ of the cost of flood insurance policies for properties in the 100-year floodplain. ${ }^{19}$ The significantly positive income elasticity means that the gap between WTP and actual price may be larger than our estimates because the mean household income of survey respondents was higher than the study area average (U.S. Census Bureau 2018). The gap would also be larger in communities that have not participated in the CRS and have not taken actions to lower NFIP premiums for residents.

The fact that we find WTP increases with income reflects both the utility received from flood insurance and a respondent's ability to pay, or the marginal utility of income. Although it is difficult to tease apart these two components of WTP, recognizing them is important for informing the ongoing policy dialogue on flood insurance affordability. Among those that can afford an insurance policy, they may not feel it provides value-that it is "not worth it" - if they fail to understand the role of insurance in their recovery, they have challenges in assessing low-probability events (Botzen and van den Bergh 2012; Meyer and Kunreuther 2017), or the policy terms do not meet their needs. There is thus a need for providing more transparent information to residents in flood-prone areas on the potential losses they can suffer from future floods and the role that insurance can play in the recovery process.

\footnotetext{
${ }^{19}$ If we code respondents who selected "I don't know" as having \$0 WTP, the median annual WTP for respondents in the 100 -year floodplain ranges from around $34 \%$ to $42 \%$ of the cost of flood insurance policies for properties in the 100year floodplain. Predicted results are in Appendix Table C3.
} 
There are also families who would value flood insurance but do not have enough disposable income to afford a policy. In our study, there is some evidence that the divergence between WTP and the price of an NFIP policy in our study area may be largely reflective of ability to pay. First, all respondents were told about the risk of flooding in the WTP question (Appendix B), and the simple act of responding to that question would have made flood risk more salient. ${ }^{20}$ The WTP question also reminded participants about what they would receive from the insurance policy and about the limitation of postdisaster aid. Second, although prior work has found risk perceptions may decline as time from a major disaster increases (Kousky 2010; Atreya, Ferreira, and Kriesel 2013; Bin and Landry 2013; Shr and Zipp 2019), our study area faces a different flood-risk profile-frequent, shallow flooding - so respondents are continually reminded of the risk. This was verified in a recent hedonic study of our area, which found a consistently lower sales price for homes in the 100year floodplain over a 25-year period (Netusil, Moeltner, and Jarrad 2019).

Given the documented role of insurance in recovery, many observers have proposed means-tested assistance, such as an insurance voucher, if inability to afford coverage is a true barrier to wider take-up (National Resource Council 2015; Dixon et al. 2017; Kunreuther 2018). Our societal preferences toward redistribution are often good- or service-specific, and there is a growing view among policymakers that in the face of increasingly costly flood events, insurance is a preferred and necessary recovery mechanism. That said, such a federal policy remains elusive. Our results, however, can help inform what magnitude of an insurance voucher would be needed to as-

\footnotetext{
${ }^{20}$ Based on answers to questions about expected future flooding (Appendix A), most respondents did not expect basement flooding over the next 30 years. On average, respondents assessed their risk as higher than would be inferred from FEMA maps. Assuming the annual risk of flooding in the SFHA is roughly $1 \%$ or greater, respondents estimate more frequent likelihood of flooding in their basement or crawlspace than an average of $1 \%$ a year over 30 years. This is also true of respondents in the 500-year floodplain, where the annual risk is $0.2 \%$.
}

sist families should Congress decide to act on this recommendation.

In response to a lack of federal policy, a few communities around the country, including Portland, have adopted their own flood insurance affordability programs. Portland's pilot program helped participating residents in Lents and Powellhurst-Gilbert lower their insurance costs through elevation certificates and insurance consultations that helped qualify them for reduced premiums through the NFIP. The program achieved an average savings of over $\$ 700$ per household (Sherman and Kousky 2018). This was accomplished without the use of direct support, such as through insurance vouchers, which could be a useful complementary policy. This pilot program could be scaled to other communities.

As climate change continues to escalate risk from a range of natural disasters, financial recovery is going to become an increasingly pressing national concern. Insurance tends to provide more funding and provides it faster than other forms of assistance, but its value is often not well communicated, and its cost can be prohibitive. To ensure equitable recovery, programs that educate potential victims about the role of flood insurance and also support the purchase of flood insurance among lower income households are needed.

\section{Acknowledgments}

Support for this research comes from the Bernard Goldhammer Grant for Research on Economics and Natural Resources, Reed College; the Stendal Fund for Economics, Reed College; the Miller and Mintz Funds for Economics, Reed College; the Travelers-Wharton Risk Management and Leadership Project; and the Wharton Risk Management and Decision Processes Center. We are grateful to Jacob Sherman, Marie Walkiewicz, Deb Meihoff, Gary Wolff, Daniel Newberry, Craig Lauder, Ben Lund, John Edgington, Aimee Sisco, Kathy Wu, Kristin Bott, David Isaac, Joe Marquez, Iliana Alcantar, Thao Dinh, Mike Kozlov, and Melody Harvey for their help with this project. Constructive feedback was received from participants in the 2019 W-4133 meetings, 2019 AERE summer meetings, and from Richard Carson, Trudy Cam- 
eron, Kelly McConville, and two anonymous referees. Florin Feiner and Ben Thomas provided research assistance.

\section{References}

AECOM. 2013. The Impact of Climate Change and Population Growth on the National Flood Insurance Program Through 2100. Arlington, VA: Federal Emergency Management Agency. Available at https://www.adaptationclearinghouse. org/resources/the-impact-of-climate-changeand-population-growth-on-the-national-floodinsurance-program-through-2100.html.

Ariely, Dan, George Loewenstein, and Drazen Prelec. 2003. "'Coherent Arbitrariness': Stable Demand Curves Without Stable Preferences." Quarterly Journal of Economics 118 (1): 73106.

Atreya, Ajita, Susana Ferreira, and Warren Kriesel. 2013. "Forgetting the Flood? An Analysis of the Flood Risk Discount over Time." Land Economics 89 (4): 577-96. https://doi.org/10.3368/ le.89.4.577.

Atreya, Ajita, Susana Ferreira, and Erwann Michel-Kerjan. 2015. "What Drives Households to Buy Flood Insurance? New Evidence from Georgia." Ecological Economics 117 (September): 153-61. https://doi.org/10.1016/j. ecolecon.2015.06.024.

Bin, Okmyung, and Craig E. Landry. 2013. "Changes in Implicit Flood Risk Premiums: Empirical Evidence from the Housing Market." Journal of Environmental Economics and Management 65 (3): 361-76. https://doi. org/10.1016/j.jeem.2012.12.002.

Board of Governors of the Federal Reserve System. 2017. "Report on the Economic Well-Being of U.S. Households in 2016." Washington, DC: Board of Governors of the Federal Reserve System.

Botzen, W. J. Wouter, and Jeroen C. J. M. van den Bergh. 2012. "Risk Attitudes to Low-Probability Climate Change Risks: WTP for Flood Insurance." Journal of Economic Behavior \& Organization 82 (1): 151-66. https://doi. org/10.1016/j.jebo.2012.01.005.

Boyle, Kevin J. 2017. "Contingent Valuation in Practice." In A Primer on Nonmarket Valuation, edited by Patricia A. Champ, Kevin J. Boyle, and Thomas C. Brown, 83-131. Dordrecht, Netherlands: Springer. https://doi. org/10.1007/978-94-007-7104-8_4.
Brody, Samuel D., Wesley E. Highfield, Morgan Wilson, Michael K. Lindell, and Russell Blessing. 2017. "Understanding the Motivations of Coastal Residents to Voluntarily Purchase Federal Flood Insurance." Journal of Risk Research 20 (6): 760-75. https://doi.org/10.1080/136698 77.2015.1119179.

Browne, Mark J., and Robert E. Hoyt. 1999. "The Demand for Flood Insurance: Empirical Evidence." SSRN Electronic Journal. https://doi. org/10.2139/ssrn.169448.

Bureau of Environmental Services. 2019. Foster Floodplain Natural Area. Portland, OR: City of Portland. Available at https://www.portlandore gon.gov/bes/article/286175.

Burke, William J. 2009. "Fitting and Interpreting Cragg's Tobit Alternative Using Stata." The Stata Journal: Promoting Communications on Statistics and Stata 9 (4): 584-92. https://doi. org/10.1177/1536867X0900900405.

Carson, Richard T., Robert C. Mitchell, W. Michael Hanemann, Raymond J. Kopp, Stanley Presser, and Paul A. Ruud 1992. "A Contingent Valuation Study of Lost Passive Use Values Resulting from the Exxon Valdez Oil Spill." MPRA Paper 6984. Munich, Germany: University Library of Germany. Available at https://mpra.ub.unimuenchen.de/6984/.

Chang, Heejun, Eric Watson, and Angela Stecker. 2017. "Climate Change and Stream Temperature in the Willamette River Basin: Implications for Fish Habitat." In Bridging Science and Policy Implication for Managing Climate Extremes, edited by Hong-Sang Jung and Bin Wang, 119-32. Singapore: World Scientific Publishing.

Chivers, James, and Nicholas E. Flores. 2002. "Market Failure in Information: The National Flood Insurance Program." Land Economics 78 (4): 515-21.

Crabtree, Charles, and Volha Chykina. 2018. "Last Name Selection in Audit Studies." Sociological Science 5: 21-28. https://doi.org/10.15195/ v5.a2.

Cragg, John G. 1971. "Some Statistical Models for Limited Dependent Variables with Application to the Demand for Durable Goods." Econometrica 39 (5): 829-44.

Dillman, Don A., Jolene D. Smyth, and Leah Melani Christian. 2014. Internet, Phone, Mail, and Mixed-Mode Surveys: The Tailored Design Method. New York: John Wiley \& Sons.

Dixon, Lloyd, Noreen Clancy, Benjamin Miller, Sue Hoegberg, Michael Lewis, Bruce Bender, 
Samara Ebinger, et al. 2017. The Cost and Affordability of Flood Insurance in New York City: Economic Impacts of Rising Premiums and Policy Options for One- to Four-Family Homes. Santa Monica, CA: RAND Corporation. https://doi.org/10.7249/RR1776.

Dixon, Lloyd, Noreen Clancy, Seth Seabury, and Adrian Overton. 2006. The National Flood Insurance Program's Market Penetration Rate: Estimates and Policy Implications. Santa Monica, CA: RAND Corporation. https://doi. org/10.7249/TR300.

Dohmen, Thomas, Armin Falk, David Huffman, Uwe Sunde, Jürgen Schupp, and Gert G. Wagner. 2011. "Individual Risk Attitudes: Measurement, Measurement, Determinants, and Behavioral Consequences." Journal of the European Economic Association 9 (3): 522-50. https:// doi.org/10.1111/j.1542-4774.2011.01015.x.

Federal Emergency Management Agency (FEMA). 2016a. FEMA Best Practices Disaster Mitigation Working in Oregon: Natural Floodplain Restoration Protects Communities. Washington, DC: Federal Emergency Management Agency.

- 2016b. Individuals and Households Program Unified Guidance (IHPUG). FP 104009-003. Washington, DC: Federal Emergency Management Agency.

— 2017. NFIP Desk Reference Guide for State Insurance Commissioners and Others. Washington, DC: Federal Emergency Management Agency.

—. 2018. FIMA NFIP Redacted Policies Data Set. Washington, DC: Federal Emergency Management Agency. Available at https://www. fema.gov/media-library/assets/documents/ 180376.

. 2019. FIMA NFIP Redacted Claims Data Set. Washington, DC: Federal Emergency Management Agency. Available at https://www. fema.gov/media-library/assets/documents/ 180374.

Henninger, Phoebe, Marc Meredith, and Michael Morse. 2018. "Who Votes Without Identification? Using Affidavits from Michigan to Learn About the Potential Impact of Strict Photo Voter Identification Laws." SSRN Scholarly Paper ID 3205769. Rochester, NY: Social Science Research Network. Available at https://papers. ssrn.com/abstract $=3205769$.

Hung, Hung-Chih. 2009. "The Attitude towards Flood Insurance Purchase When Respondents' Preferences Are Uncertain: A Fuzzy Approach.”
Journal of Risk Research 12 (2): 239-58. https:// doi.org/10.1080/13669870802497702.

Imai, Kosuke, and Kabir Khanna. 2016. "Improving Ecological Inference by Predicting Individual Ethnicity from Voter Registration Records." Political Analysis 24 (2): 263-72. https://doi. org/10.1093/pan/mpw001.

Jarrad, Maya. 2016. Johnson Creek Restoration Sites 1990-2014. Harvard Dataverse, V3. Cambridge, MA: Harvard University. Available at https://dataverse.harvard.edu/dataset.xhtml? persistentId=doi:10.7910/DVN/L4DDCR.

Johnston, Robert J., Kevin J. Boyle, Wiktor Adamowicz, Jeff Bennett, Roy Brouwer, Trudy Ann Cameron, W. Michael Hanemann, et al. 2017. "Contemporary Guidance for Stated Preference Studies." Journal of the Association of Environmental and Resource Economists 4 (2): 319405. https://doi.org/10.1086/691697.

Joyce, Christopher. 2016. "Outdated FEMA Flood Maps Don't Account For Climate Change." NPR radio broadcast, September 15. Available at https://www.npr.org/2016/09/15/492260099/ outdated-fema-flood-maps-dont-account-forclimate-change.

Jung, Il-Won, Heejun Chang, and Hamid Moradkhani. 2011. "Quantifying Uncertainty in Urban Flooding Analysis Considering Hydro-Climatic Projection and Urban Development Effects." Hydrology and Earth System Sciences 15 (2): 617-33. https://doi.org/10.5194/hess-15-6172011.

Khanna, Kabir, and Kosuke Imai. 2019. Wru: Who Are You? Bayesian Prediction of Racial Category Using Surname and Geolocation (version 0.1-9). Available at https://CRAN.R-project. org $/$ package $=$ wru.

Kousky, Carolyn. 2010. "Learning from Extreme Events: Risk Perceptions after the Flood." Land Economics 86 (3): 395-422.

- 2011. "Understanding the Demand for Flood Insurance." Natural Hazards Review 12 (2): 96-110. https://doi.org/10.1061/(ASCE) NH.1527-6996.0000025.

Kousky, Carolyn, Brett Lingle, and Leonard Shabman. 2017. "The Pricing of Flood Insurance." Journal of Extreme Events 4 (2): 1750001. https://doi.org/10.1142/S2345737617500014.

Kriesel, Warren, and Craig Landry. 2004. "Participation in the National Flood Insurance Program: An Empirical Analysis for Coastal Properties." Journal of Risk and Insurance 71 (3): 405-20. https://doi.org/10.1111/j.00224367.2004.00096.x. 
Kunreuther, Howard. 2018. "Improving the National Flood Insurance Program." Behavioural Public Policy, 1-15. https://doi.org/10.1017/ bpp.2018.26.

Kunreuther, Howard, and Erwann Michel-Kerjan. 2015. "Demand for Fixed-Price Multi-Year Contracts: Experimental Evidence from Insurance Decisions." Journal of Risk and Uncertainty 51 (2): 171-94. https://doi.org/10.1007/ s11166-015-9225-4.

Landry, Craig E., and Mohammad R. Jahan-Parvar. 2011. "Flood Insurance Coverage in the Coastal Zone: Flood Insurance Coverage in the Coastal Zone." Journal of Risk and Insurance 78 (2): 361-88. https://doi.org/10.1111/j.15396975.2010.01380.x.

Lee, Karl K., and Daniel T. Snyder. 2009. Hydrology of the Johnson Creek Basin, Oregon. Washington, DC: U.S. Geological Survey. Available at http://pubs.usgs.gov/sir/2009/5123/.

Lin, Ning, Robert E. Kopp, Benjamin P. Horton, and Jeffrey P. Donnelly. 2016. "Hurricane Sandy's Flood Frequency Increasing from Year 1800 to 2100." Proceedings of the National Academy of Sciences 113 (43): 12071-75. https://doi.org/10.1073/pnas.1604386113.

McClelland, Gary H., William D. Schulze, and Don L. Coursey. 1993. "Insurance for Low-Probability Hazards: A Bimodal Response to Unlikely Events." In Making Decisions About Liability And Insurance: A Special Issue of the Journal of Risk and Uncertainty, edited by Colin Camerer and Howard Kunreuther, 95-116. Dordrecht, Netherlands: Springer. https://doi. org/10.1007/978-94-011-2192-7_7.

Metro Data Resource Center. 2016a. RLIS Discovery: Home-Flood Plains (FEMA). Portland, OR: Metro Regional Government. Available at http://rlisdiscovery.oregonmetro.gov/?action =viewDetail\&layerID=1756\#.2016b.

- 2016b. RLIS Discovery: Home-Rivers (Line). Portland, OR: Metro Regional Government. Available at http://rlisdiscovery.oregon metro.gov/?action=viewDetail\&layerID $=1556$.

— 2018. RLIS Discovery: Home-Taxlots. Portland, OR: Metro Regional Government. Available at http://rlisdiscovery.oregonmetro. gov/?action=viewDetail\&layerID $=41 \#$.

Meyer, Robert, and Howard Kunreuther. 2017. The Ostrich Paradox: Why We Underprepare for Disasters. Philadelphia: The Wharton School Press.

National Academies of Sciences, Engineering, and Medicine. 2019. Framing the Challenge of Urban Flooding in the United States. Washing- ton, DC: National Academies Press. https://doi. org/10.17226/25381.

National Oceanic and Atmospheric Administration. 2019. Historical Crests for Johnson Creek near Sycamore. Washington, DC: National Oceanic and Atmospheric Administration, Advanced Hydrologic Prediction Service. Available at https://water.weather.gov/ahps2/crests. php $?$ wfo $=$ pqr $\&$ gage $=$ syco3 $\&$ crest_type $=$ his toric.

National Research Council. 2015. Affordability of National Flood Insurance Program Premiums: Report 1. Washington, DC: National Academies Press. https://doi.org/10.17226/21709.

Netusil, Noelwah R., Klaus Moeltner, and Maya Jarrad. 2019. "Floodplain Designation and Property Sale Prices in an Urban Watershed." Land Use Policy 88 (November): 104-12. https://doi. org/10.1016/j.landusepol.2019.104112.

Office of Inspector General. 2017. FEMA Needs to Improve Management of Its Flood Mapping Program. Washington, DC: Department of Homeland Security. Available at https://www. oig.dhs.gov/sites/default/files/assets/2017/ OIG-17-110-Sep17.pdf.

Oregon Solutions. 2017. Lents Stabilization and Job Creation Collaborative. Portland: Oregon Solutions. Available at http://orsolutions.org/ osproject/lents-stabilization-and-job-creatingcollaborative.

Peri, Caroline, Stephanie Rosoff, and Jessica Yager. 2017. Population in the U.S. Floodplains. New York: New York University Furman Center.

Petrolia, Daniel R., Craig E. Landry, and Keith H. Coble. 2013. "Risk Preferences, Risk Perceptions, and Flood Insurance." Land Economics 89 (2): 227-45. https://doi.org/10.3368/ le.89.2.227.

Roder, Giulia, Paul Hudson, and Paolo Tarolli. 2019. "Flood Risk Perceptions and the Willingness to Pay for Flood Insurance in the Veneto Region of Italy." International Journal of Disaster Risk Reduction 37 (July): 101172. https:// doi.org/10.1016/j.ijdrr.2019.101172.

Royal, Andrew, and Margaret Walls. 2019. "Flood Risk Perceptions and Insurance Choice: Do Decisions in the Floodplain Reflect Overoptimism?" Risk Analysis 39 (5): 1088-104. https:// doi.org/10.1111/risa.13240.

Seifert, Isabel, W. J. Wouter Botzen, Heidi Kreibich, and Jeroen C. J. H. Aerts. 2013. "Influence of Flood Risk Characteristics on Flood Insurance Demand: A Comparison between Germany and the Netherlands." Natural Hazards and Earth 
System Sciences 13 (7): 1691-705. https://doi. org/10.5194/nhess-13-1691-2013.

Shah, Paru R., and Nicholas R. Davis. 2017. "Comparing Three Methods of Measuring Race/Ethnicity." The Journal of Race, Ethnicity, and Politics 2 (1): 124-39. https://doi.org/10.1017/ rep.2016.27.

Shaw, Al, Christie Thompson, and Theodoric Meyer. 2013. "Federal Flood Maps Left New York Unprepared for Sandy-and FEMA Knew It." ProPublica, December 6. Available at https://www.propublica.org/article/federalflood-maps-left-new-york-unprepared-forsandy-and-fema-knew-it.

Sherman, Jacob, and Carolyn Kousky. 2018. Local Solutions to Flood Insurance Affordability: Portland's Flood Insurance Savings Program. Issue Brief. Philadelphia: Wharton Risk Management and Decision Processes Center.
Shr, Yau-Huo, and Katherine Y. Zipp. 2019. "The Aftermath of Flood Zone Remapping: The Asymmetric Impact of Flood Maps on Housing Prices." Land Economics 95 (2): 174-92. https://doi.org/10.3368/le.95.2.174.

StataCorp. 2019a. Stata Base Reference Manual Release 16: Intreg. College Station, TX: Stata Press.

. 2019b. Stata Base Reference Manual Release 16: Stintreg. College Station, TX: Stata Press.

U.S. Census Bureau. 2018. "2013-2017 American Community Survey Summary File." Washington, DC: U.S. Census Bureau. Available at https://www.census.gov/newsroom/press-kits/ 2018/acs-5year.html.

Wooldridge, Jeffrey M. 2019. Introductory Econometrics: A Modern Approach. Boston, MA: CENGAGE. 